\title{
Ulisse all'Isola di Circe (Brussels 1650): Operatic Transformation of Classical Tradition and Dissolution of Stoic Problems
}

\author{
PIOTR URBAŃSKI \\ Adam Mickiewicz University \\ Instytut Filologii Klasycznej \\ Uniwersytet im. Adama Mickiewicza \\ ul. Fredry 10 \\ 61-701 Poznań, Poland \\ urbanski@amu.edu.pl
}

\begin{abstract}
The present article is a close reading of the libretto of the first opera (drama musicale) staged in the Netherlands, in Brussels in 1650. The main point of interest is Ascanio Amalteo's transformation or even breakaway from the classical tradition (esp. Homer and Ovid) to create a work with its own message, quite distant from classical texts but, paradoxically, approaching moral and psychological categories in Neo-Stoic mode. Perhaps it is not by chance that a parallel piece, Calderón's second play on Circe (after the fiesta entitled El mayor encanto, amor, 1635), i.e. the auto sacramentale entitled Los encantos de la culpa (ca. 1650), is also a significant transformation of the motive done in the spirit of the Counter-Reformation. Both plays are the last allegorical interpretations of Circe myth and for the next two-hundred years the last important literary works about Ulysses.
\end{abstract}

Keywords: Ulysses; Circe; opera in the Netherlands; libretto; classical tradition and its transformation; Neo-Stoicism; virtues (constancy, temperance); emotions

Ulisse all'Isola di Circe - drama musicale by the Italian composer Gioseffo Zamponi and the poet Ascanio Amalteo - was commissioned by the archduke Leopold Wilhelm of Hapsburg, governor of the Netherlands, to celebrate the wedding 
of the king Philip IV of Spain and Maria Anna of Austria. ${ }^{1}$ It was staged in the archduke's Brussels palace twice in February 1650, as well as five years later on the occasion of the visit of the former Queen Christina of Sweden in the city. It was the first production of opera theatre in the Netherlands - the first and the only one for almost thirty years, until 1677 (Amsterdam) and 1681 (Brussels) (Rasch 1999: 430-431). ${ }^{2}$ It should be mentioned that it was very splendid production engaging three hundred singers, musicians, dancers etc., with nine changes of decorations and thirteen machines. ${ }^{3}$ Sigrid T'Hooft (2008: 87) writes:

The making of Ulisses was very clearly an Italian affair. Composer Giuseppe Zamponi, choreographer Giovanni Battista Balbi, librettist Ascanio Amalteo and stage designer Giovanni Battista Angelini, although thrown together more or less by accident, produced an amazingly graceful and coherent piece of musical theatre.

The present article is a close reading of the libretto of the opera. The main interest is the poet's transformation or even breakaway from the classical tradition (esp. Homer and Ovid) to create a work with its own message, quite far from classical texts but, paradoxically, approaching moral and psychological categories in Neo-Stoic mode. The main argument is that the opera is a dramatic discussion with the Stoic understanding of emotions, constancy, and other fundamental categories. Nevertheless, the poet's argumentation and polemic is not always serious. Especially the dissolution of Stoic problems is possible only thanks to the deep transformation of classical tradition and employing new features in the person of Ulysses. The Stoic discussion is here twofold: in words of characters and in the plot, including its very peculiar ending. What is interesting there is not possible to find any Christian connection of the text.

Perhaps it is not by chance that a parallel piece, Calderón's second play on Circe (after the fiesta entitled El mayor encanto, amor, 1635), i.e. the auto sacramentale entitled Los encantos de la culpa (ca. 1650), is also a significant transformation of

\footnotetext{
1 "The marriage festivities took place in Madrid December 1649, but neither Philip IV nor Maria Anna were present at the Brussels Ulisse performances in their honour in 1650. This was Philip's second marriage, and all the Spanish territories hoped that it would mark the beginning of a long-awaited period of peace, after thirty years of war." (T'Hooft 2008: 87). It should be mentioned that success of Neo-Stoicism, discussed in the present article, was closely connected to the political situation in many European countries.

${ }^{2}$ There has been no modern production of the opera. It was planned for 2000 in Brussels but the plans were ultimately abandoned. The only recording was released in 2014 (Ricercar): Capella Mediterranea, Clematis, Choeur de Chambre de Namur, Leonardo García Alarcón (direction). There are only two articles about the opera: Haas 1920-1921 and T'Hooft 2008; some information can be found in the three essays in the booklet to the mentioned recording. The most recent contribution on Ovidian motives in operas (Solomon 2014) does not include Ulisse all'Isola di Circe.

${ }^{3}$ All quotations from the libretto are from the 1650 edition of the libretto (a copy preserved in Herzog August Bibliotek Wolfenbüttel). The libretto printed in the booklet to Ricercar recording omits some parts of the additional text but adds some summaries of the scenes possibly taken from the score (also quoted here). English translation of the libretto by Peter Lockwood quoted after the booklet.
} 
the motive done in the spirit of the Counter-Reformation. Both plays are the last but extremely different (allegorical) interpretations of Circe myth and for the next two-hundred years the last important literary works about Ulysses.

\section{Early modern sources}

It is clear that the rewriting of the Homer's story (Odyssey bk. 10) made by Amalteo is quite independent both from classical sources and their ancient allegorical interpretations, as well as medieval and early modern tradition of Circe (see Yarnall 1994; Kuhn 2003; Tochtermann 1992; Stanford 1963; Capodieci and Ford 2011). The most influential Renaissance manual of mythology by Natalis Comes (1551) collected all classical sources in bk. VI chap. VI and follows such ethical explanation of Circe in bk. X Quod omnia philosophorum dogmata sub fabulis contiebantur:

Circe libido est, quae nascitur ex humore \& calore in animalibus. Haec titillatio naturae si nobis dominetur, beluarum vitia in animis nostris imprimit, \& pro cuiusque ingenio modo in Veneres impellit, modo ad iram perducit, modo crudelitatis \& improbitatis omnis vim nobis imprimit: quare dicti sunt comites Ulyssis, animae motus scilicet, in beluas diversarum formarum conversi. Sed quoniam ad hoc nonnihil impellit vis siderum, dicta est sidera etiam de coelo deducere at anima quae prudens \& divina existit, si modo se colligat, nullis horum motuum capitur: neque tamen sine divina ope hanc tantum voluptatum periculorumque multitudinem potest superare. Haec enim per hanc fabulam antiqui innuebant. (Comes 1612: 1039-1040)

[Circe is a kind of lust which arises in living beings (animals) from humidity and heat. If this excitation of nature takes hold over us it imprints beastly vices in our souls and moves everyone in a natural way into fornication, it then leads to anger and then imprints in us all the seed of cruelty and depravity: that is why it was said about the companions of Ulysses, that they, as the movements of the spirit, were turned into creatures of various forms. But because the power of stars also moves us to a certain point - people say that the stars lead to heaven - but the soul which is prudent and pious, if it then pulls itself together, it is influenced by none of these movements: but it is not able to overcome such a multitude of lust and danger without God's help. The ancients have said this through this story.]

The description of Circe can be found also in the two influential books by Giovanni Boccaccio Genealogia deorum gentilium (1360-1374, bk. V chap. 14) and 
De claris mulieribus (1374, chap. 38). In the second work he speaks surprisingly about Circe's prudent deeds: "Solis, ut arbitior, ideo filia dicta, quia singulari floruerit pulchritudine seu quia circa notitiam herbarum fuerit eruditissima vel potius qua prudentissima in agendis" (Boccaccio 2013: 220) ["In my opinion, she was called the daughter of the Sun because she had singular beauty, or because she was very skilled in the knowledge of herbs, or rather because she was very shrewd in conducting her affairs" (Boccaccio 1963: 77)], despite later negative moral description:

Et sic hi quibus infauste mulieris opera humana subtracta videbatur ratio eos ab eadem in sui facinoris feras merito crederetur fuisse conversos. Ex quibus satis comprehendere possumus hominum mulierumque conspectus moribus multas ubique Cyrces esse et longe plures homines lascivia et crimine suo verso in belluas. Ulixes autem Mercurii consilio predoctus prudentem virum satis evidenter ostendit quem adulantium nequeunt laqueare decipule, quinimo et documentis suis laqueatos persepe solvit a vincula. (Boccaccio 2013: 222)

[She made many men become haughty because of her matchless attraction, and so those who through this wicked woman's deeds appeared to have lost human reason seemed to have been deservedly changed into beasts through their own crimes. If we consider human behaviour, we can well understand from this example that there are many Circes everywhere and many other men are changed into beasts by their lustfulness and their vices. And Ulysses, instructed by Mercury's advice, obviously signifies that wise man who cannot be bound by the trickery of deceitful people and who by his example often loosens the bonds of those who are held. (Boccaccio 1963: 78)]

\section{The concept of Amalteo's plot}

There is no information on Amalteo ${ }^{4}$ and his literary background so all statements about the sources of his libretto and its transformation of classical tradition are only conjectures as well as the opinion of the poet's aim of changing classical version of the tale about Ulysses on the isle of Circe. Nevertheless, many important details are very distant from the canonical texts (Homer Odyssey bk. 10, Virgil Aeneid bk. 7, Ovid Metamorphoses bk. 14 - the last one was the most influential source for the Circe-related texts in the $17^{\text {th }}$ century). Some changes

\footnotetext{
${ }^{4}$ The name of the author is not given on the title page of the score and the printed libretto. The attribution is based only on the first liminary verses in the libretto, signed by Amalteo.
} 
are apparently the invention of Amalteo subordinated to both the new plot and the tendency or the main idea of the opera. According to Baroque practice there were two places when poet could and should express his concept: the argument (argomento), a kind of summary with interpretative accents, and prologue which employed allegorical and/or mythological characters. In the case of Amalteo they are firstly not relevant or equal in meaning, and secondly, the prologue does not reveal the core idea, explained only in the dialogue-quarrel between Mercurio and Venere in the second act (sc. 5) where the god openly employs Stoic argumentation:

Chi s'arma di virtù sue voglie abbatte, E sempre invitto con Amor combatte.

$[\ldots]$

Hor hora si vederà

Farò ben che da te,

Volga rubello piè

Chi tra lacci e di beltà.
He who is armed with the virtue breaks love's wishes And is always unconquered in the struggle.

$[\ldots]$

We shall soon see:

I shall arrange that

The rebel caught by bonds

And beauty escapes you.

The poet writes in the argument:

Confessate che hebbe l'incenerita Troia nella sua fatale ruina, vittoriose le greche spade, altro non restaua, che à loro Principi, per cui haueua combattuto la forte, machinassero i tutelari de Troiani per vendetta, intempestiue persecutioni. Vlisse Re d'Ittaca, che portaua seco gran parte dell' asiatiche palme, fù destinato per scopo infelicissimo de sdegni di piu una Deità. Superati, con la scorta della virtù, \& con la compagnia della fortuna, pericoli de piu inaccessibili, e naufragij de piu crudeli, fù spinto all' isola della maga Circe. Vna squadra de soldati del greco Eroe, commandati à riconoscerla, entrati nella magica stanza alla violenza di quell' arte, impetriono all' improuiso, \& vi restorno statue. Euriloco solo, che haueua trattenuto il passo fù la soglia dell' antro, trattenne anche il suo destino; stupì alla vista dell' effetto, e riuolto il passo, raguaglionne Vlisse; l'Eroe chiedendo al proprio sdegno le accostumate maniere per vendicarsene, ricueuè da Mercurio Nume fauoreuole, insegnamenti opportuni; e spintosi alla volta di Circe; andò, vidde, e vinse la forza de suoi incanti, mà non già quella di lei bellezza; \& ardendo, e la trionfatrice, e il trionfante di fiamma eguale, furno i primi segni delle correspondenze amorose, la restituzione che de proprij aspetti fece la Maga amante, à graditi seguaci dell' adorato Campione. Qual trattenuto da vezzi, \& imprigionato tra lusinghe, perdeua di già vanamente, quanto penosamente haueua acquistato. La tutela del Dio che li assisteua, la reflessione del proprio essere, l'amor della Patria, l'affeto della mogle, la tenerezza del figlio, e gl'interessi del Regno, lo stimolorno; 
Ne restò persuaso. Abandonò la maga alle furie, \& alla disperatione, rompè ogni indugio, e partì. Venere partiale delle lasciuie di Circe, si portò in cielo per incolpare al tribunal di Gioue di spergiura la partenza d'Vlisse. Mercurio la seguì, per sostentar la difesa, \& per autorizar quei dogmi, che alla salute dell'Eroe, haueua saggiamente tra le condannate lasciuie di Circe, contro Circe esagerati.

[Troy had been reduced to ashes and to the ruin that was its destiny; the Greeks were victorious and all that the Trojans' tutelary deities were able to do was to plot several vengeful and excessive persecutions of the Greek princes on whom fate had smiled. Ulysses, king of Ithaca, had himself won a large part of the honours of the final victory and was therefore fated to be the unhappy target of the rancorous anger of more than one deity. Having defeated unimaginable perils and terrible shipwreck thanks to good fortune and to his own merits, Ulysses was driven to the island of sorceresses Circe. He had ordered a squadron of his solders to explore the island; they entered Circe's enchanted palace and were immediately turned to stone by her enchantments, remaining there as statues. Eurilochus was the only one to avoid this fate, as he had avoided entering the palace; aghast at the transformation that he beheld, he returned to inform Ulysses. The hero realised that the only weapon for vengeance that he possessed was his wrath; the god Mercury then favoured him and gave him much sage advice. He went to meet Circe; he saw her and was able to defeat her powerful sorcery, but was powerless against the spell of her beauty. Each had victory over the other; desire flared in them both and the first signs of reciprocal passion soon appeared. The sorceress transformed her beloved champion's soldiers back to their normal forms, whilst he, ensnared by her beauty and her enchantments, slowly caused him to lose all that he had so painfully gained. Mercury's protection, the realisation of what he had become, the love of his country, his desire for his wife, his tender feeling for his son and his concern for his kingdom all united to convince him: he brushed aside all Circe's attempts to delay him and departed, leaving her to her fury and despair. Venus, who had approved of Circe's amorous activities, travelled through the heavens to Jupiter's judgement seat and accused Ulysses of betrayal because of his abandonment. Mercury followed her to act in Ulysses' defence and to justify the sometimes excessive means that he had cunningly deployed against Circe and her reprehensible lusts.]

The idea of a double victory is very interesting: both Ulisse and Circe are victors and victims, both were vulnerable to their (sexual) spell and magic, as well 
as their own passions and desire: "Che più che donatrice, a lui son dono" ["That I myself am the gift and not the giver"] - speaks Circe to Venere (act II, sc. 4). Circe could survive only thanks to the intervention of Venere and only goddess' yearning for vengeance changed the course of events. Ultimately, there is no solution and salvation: the abandoned Circe stays in fury and despair, whereas Ulisse as a Stoic hero is admonished by Mercurio of his destination and obligations. There is no typical lieto fine. Furthermore, the arguments of Mercurio and Venere seem equal and Giove's judgement is needed. The poet does not reveal the judgement in order to avoid an early disclosure. Consequently, the spectator, although generally knowing the plot of the opera, is held in suspense until its very end.

The angered Nettuno ${ }^{5}$ in the prologue of the opera "querella della poca obedienza del suo Regno" ["He laments how little he is obeyed in his own realm"] and only incidentally mentions Ulisse: "Ne potrò far ch'il temerario Ulisse / Riporti de suoi error, degno castigo?" ["And shall I not ensure that the rash Ulysses / Receives a fitting punishment for his error?"], but there is no explanation what the hero's error actually was. The reader can only assume that it was sexual intercourse with Circe but for the reader of Homer it is clear that it was ordered by Hermes. Only Secondo Tritone explains that it was Venere who descended upon the isle and was the author of Ulisse's misfortune. Secondo Tritone also calls him "l'arrischiato guerriero" ("the daring warrior") for the first time which is the frequent name of Ulisse in the opera and suggests both that he is recognized by the acting persons rather as a hero of Iliad than Odyssey as well as suggests the main feature of his behaviour and his spiritual struggle. Circe also recognizes him as a warrior: "Guerrier, deh ferma l'ire" ["Warrior, control your anger"] (act I, sc. 6). This name is the core of Mercurio persuasion to Ulisse (act II, sc. 3); he is a warrior not a lover: "Con alto sapere / Farò che constant / Ulisse sia guerrier ma non Amante. // [...] Ulisse non ama / Ma saggio e constant / Farò che sia Guerrier ma non Amante. / [...] Ogni danno ripara / Huom saggio, se precede I suoi perigli." ["My high arts / Will ensure that the faithful Ulysses / is a warrior, but not a lover. // [...] Ulysses will not like this, but / I, wise and faithful, will ensure / That he is a warrior and not a lover. [...] A wise man can prevent any harm / If he anticipates trouble."]

Aria $a$ which ends the prologue explains that it is a battle between love and reason, desire and obligation:

\footnotetext{
${ }^{5}$ The reason of his anger is that his power and rule are too weak. Secondo Tritone explains with a dose of irony: "Troppo tenti sapere / O Duce, non più Duce, / Cedi Io scettro pur cedi l'Impero, / A più di te dominator possente, / Fatto è dal sommo Giove / Sommo Rettore dell'ondoso Regno, / Nume di te più degno." ["You seek to know too much, / O ruler who rules no longer. / Cede the sceptre and the empire / To one more powerful than yourself: / A worthier god than you / Has been made Ruler of the Watery Realm / By all-powerful Jupiter."]
} 
Son più belli oggi nel mani.

Le fiammella d'amor,

che in ciel le stelle.

Su destate ninfe chiare

Tutti ardori e tutto foco

Nell imperio dell'onde

Il riso el gioco.
Today in our hands

The flames of love are fairer

Than the stars in the sky.

Up now, ye bright nymphs,

All ardour and fire,

And awaken laughter and joking

In the kingdom of the waves.

Apparently, this is not enough to understand fully the message of the libretto so the message must be clarified by the aria of Venus (act I, sc. 4) on her wrath as the reason of Ulisse's misfortune: "Non v'èforza in un core / che vaglia à supercar forza d'Amore" ["The heart has no power / That can overcome the power of love"], especially, when the situation has been arranged by herself and Circe is "Donna saggia a bella" ["a wise and fair Women"].

Finally Mercurio and Venere who are fighting for the soul and virtue of Ulisse decide to leave the judgement to Giove (act III, sc. 6). "Venere si rammarica della partenza d'Ulisse e si duole perssuasioni di Mercurio; il quale comparendo dice le sue ragioni; e l'uno doppo l'altra volano al Cielo per ventillar h'inanzi Giove." ["Venus is upset about Ulysses' departure and laments Mercury's arguments; Mercury appears and explains his reason. They both fly to heaven to state their cases before Jupiter."]. Mercurio sings at the end of the scene:

E poiché colà sù sopra le sfere,

Deue alla mie ragioni

Proceder tuo lamento,

Ne sia giudice Giove, io son contento.
Since there, above the heavenly spheres,

Your complaint must

Precede my defence,

Let Jupiter be the judge: I am content.

Giove appears in the very last scene of the third act but he avoids the question and initiates the final chorus of gods and goddesses (Marte, Pallade, Apollo, Venere) to express the political message of the opera, i.e. an eulogy of the newlyweds and to complete the homage of nations started in previous ballet scenes, inserted in the plot. ${ }^{6}$ Consequently, the quarrel of Mercurio and Venere is not resolved.

If we consider that the plot ends with the sorrowful farewell of Ulisse and Circe, it is not easy to understand that Amalteo decided to isolate this story from the whole plot of Odyssey and there is no possibility for further events described by Homer such as Ulysse's katabasis and instructions given to him by Circe about the next stages of his journey. Consequently, Circe cannot be the supportive

6 "The allegory presented by the ballet [Balet $d u$ Monde, i.e. idea of nations and mythological figures represented Joy, Longing, Hope, Love, the Four Elements and the Four Seasons], however, honours the royal couple far more than does the opera" (T'Hooft 2008: 92). 
goddess and becomes only a moral obstacle on his way back home. Such a retelling of Homer's story makes it very pessimistic and morally ambiguous. Ulisse in neither the Stoic sage nor the ideal homo viator of the ancient allegorical tradition, strong and self-possessing, free from any external influences, expressing virtues such as constancy, patience, prudence, and fortitude. He is not an emblem of nostalgia for spiritual aspirations (Stanford 1963: 78, 121, 125, 175, passim). It is very interesting that his protagonist many times hails him as combatante and guerrier. Only Ulisse's divine protector, Mercurio, dares to accuse him of effeminacy."Dunque, ancora si teme, / Effeminato Ulisse?" ["Is this effeminate Ulysses / Still to be feared?"] - he speaks to urge Ulisse to leave Circe's island when it seems that she and Venere won (act III, sc. 3).

\section{Mercurio}

In his classical book on Christian interpretation of Greek myths Hugo Rahner writes about Ulysses:

He stands between Hermes and Circe. Both the bright messenger of gods and the dark mistress of the cave are seeking to win him. These two figures represent the same ideas as the white flower of moly and its black root (Rahner 1971: 190).

Amalteo's Mercurio, as Homer's Hermes, appears to Ulisse by his own decision, not sent by Zeus as in the case of Calypso: "a divine helper appears, advising him how to approach a powerful female figure. As result, a forewarned Odysseus now approaches Kirke" (Louden 2007: 173). Ulisse meets the god, disguised as a shepherd, and obtains instructions. He is recognized only in the end of the scene and the reason of this is unmotivated. He has no magic wand and Ulisse does not know that moly can be possessed only by god (see De Jong 2001: 260).

Mercurio hails Ulisse by well-known epithets as a wise and knowledgeable men (act I, sc. 3):

Nova gioia ah non alletti

Pronto cor incauto piè

Huom che sà, raro dà fè

A promesse di diletti.

Fan così l'alme sagaci,

Che son le gioie perlo più fallaci.
Careless feet, do not tempt

An eager heart with new joys.

A knowledgeable man will rarely trust

Promises of future pleasures.

Wise souls know by this

That their joys are but fleeting.

However, he calls Ulisse's desire to find Circe's cave a folly ("È folle il tuo desire" ["Your wish is folly"]) what calls into question his previous opinion. 
Anyway, the god's protection is needed to conquer all deceit ("Chi difeso è dal ciel, vince ogni inganno" ["He whom heaven protects conquers all deceit"], act I, sc. 3). And only after this statement Ulisse recognises the god who will protect and guide him:

Mà che miro, oh stupore,

O mia speme, ò mio Nume, ò mia difesa.

Hora ti riconosco,

O gran figlio di Maia,

Gratie douute, à tua pietade, io rendo,

Prostrato à te dauanti

Saran le glorie mie, solo tui vanti.

\author{
But what do I behold? O amazement, \\ My hope and my god, my shield, \\ Now I recognise you, \\ O great son of Maia. \\ I give thanks for your mercy; \\ Prostrate before you, \\ My glory will be your triumph.
}

\section{Other gods and goddesses}

In the Odyssey Hermes is the only Olympic god who is allowed to be present on the isle of Circe, i.e. far away from humanity and civilization (Yarnall 1994: 12). Amalteo did not understand his uniqueness and placed on the Circe's island also Venere who becomes Mercurio's opponent. There are also other gods: Nettuno in the prologue, Giove at the end of the opera, as well as four gods in the final chorus. He employed also a comical figure of Satiro (act I, sc. 8) who is Circe's gardener and keeper of her fold of transformed beasts.

Venere is a counterpart of Mercurio. She wants vengeance on "crudelissimo Ulisse" ["the most cruel Ulysses"] (act I, sc. 4) but does not explain the reason of her wrath. For her Circe she protects is "Donna saggia e bella" ["a wise and fair Women"]. No one can overcome the power of love: "Non v'è forza in un core / che vaglia à supercar forza d'Amore" ["The heart has no power / That can overcome the power of love"]. These words could be used in the prologue because they explain very well one of the main ideas of the plot, just as e.g. Amor's statement in L'incoronazione di Poppea by Monteverdi where the god challenges Fortune and Virtue: I shall prove, he says, in this one battle, that neither Fortune nor Virtue but I am a ruler of the world.

\section{Circe's metamorphoses}

The change of Ulysses' crew into swine is the first metamorphose of human beings into other ones described by Greek literature. It should be stressed here that in the opera despite the whole tradition Ulysses' companions are transformed 
not into animals but into marble statues. ${ }^{7}$ It is possible that the motive was invented by Amalteo himself (I do believe so) or borrowed from another Baroque source, possibly the opera Ulisse errante (Venice 1644, libretto by Giacomo Badoaro written for Claudio Monteverdi, but set to the music by Francesco Sacrati). It is not possible to make any final statement about Amaleto's knowledge of this piece due to the lack of any biographical information about the poet. It is not certain whether Badoaro's singing marble statues are actually Ulisse's companions. ${ }^{8}$ Probably Amalteo decided to change the transformation as more suitable for the court theatre and based his concept on the story from Ovid's Metamorphoses (bk. 14) about the marble statue of Picus kept in Circe's palace and shown to the narrator Macareus by one of her servants:

illa mihi niveo factum de marmore signum

ostendit iuvenale gerens in vertice picum,

aede sacra positum multisque insigne coronis.

quis foret et quare sacra coleretur in aede,

cur hanc ferret avem [...] (Met. 14: 313-317).

[Nymph pointed out to me a snow-white marble statue of a young man with a woodpecker on his head. The statue was set in a sacred fane and attracted attention for its many wreaths. When in my curiosity I asked who it was and why he was worshipped in that holy place and why he had the bird upon his head...]

Circe who had fallen in love with Picus, the handsome first king of Latium, could not win his heart with her own attractiveness and magic, and as a punishment for his rejection transformed him into woodpecker (Met. 14: 320-415). According to Ovid, the marble statue of Picus with the bird on his head was later on worshiped in the holy place of Circe.

It is also possible that the motive of transformation into marble statues is an effect of Amalteo's contamination of Circe and Medusa - described by mythographers as the only creature who changes people into stones (Ovid, Met. bk. IV, 767f; "vidisse hominum simulacra ferarumque / in silicem ex ipsis visa conversa

\footnotetext{
${ }^{7}$ The transformed companions are described by Euriloco: "A l'innata di lor forte possanza, / Ch'havean nel guerreggiare / Qual impetrita e stabile constanza." ["The great inner strength / That they possessed for warfare / Has solidified into unmoving constancy."] - which is a kind of joke on the one of fundamental Stoic categories (act I, sc. 2). See treatises De constantia sapientis by Seneca and De constantia by Justus Lipsius (1584).

${ }^{8}$ See Badoaro act II, sc. 5, both libretto and summary. This scene employs Damigelle, Compagni di Ulisse, and Statues. So it is no sure that that were companions who had been converted into statues. In sc. 2: "doue trasformati in animali bruti sono trattenuti i di lui Compagni" [“Where were kept two of his companions transformed into ugly animals"] (Scenario, Badoaro 1644a: 31-32); "Statue: Quanti sembrano in viso e statue e marmi / C'han pronte à danni altrui le prose, e i carmi." ["How many of them look like statues and marble figures / which have prepared proses and songs for harm of another."] (Attione seconda: Nell'Isola di Circe, Badoaro 1644b: 55).
} 
Medusa" ["he saw the forms of men and beasts changed into stone by one look at Medusa's face"], ibidem, 780-781). A medieval commentator writes:

Moreover, the poets said that Medusa transformed those who looked at her into stones, i.e., that those stopped to consider her beauty and countenance so dawdled in wonder and were so troubled that there was no more sense, or movement, or understanding left them than in a stone. (Anonymous commentary from Chees of Love as quoted by Brumble 1998: 142)

Obviously, the consciousness of Ulysses' companions is very important for Amalteo: they not only have the full ability to think and feel their cruel fate but can speak/sing and enter dialogue with their master (act II, sc. 1).

According to Mercurio, Circe is able to transform humans both into (wild) beasts and statues (act I, sc. 3). Her maidens comically enumerate animals in which their lovers should be changed: peacock, piglet, stag, cat, dove, and - surprisingly "pacifico Asinello" ["a pacific donkey"] (perhaps Argesta knows very well that for Romans donkey was a symbol of wild sexuality, as in Apuleius' Metamorphoses...; act I, sc. 5), and even dolphins (despite their symbolical meaning, as an sexual entertainment for the aged Argesta).

\section{Amalteo and Calderón}

It is not possible to prove that Amalteo was familiar with Calderón's first play about Circe, the comedy (fiesta) El mayor encanto, amor [Love the Greatest Enchantment, 1635], as well as that Calderón's second play on this topic, the auto sacramental entitled Los encantos de la culpa [The Sorceries of Sin, ca. 1650] was influenced by the opera Ulisse nell' isola di Circe. ${ }^{9}$ Nevertheless, the two of them, the auto and the opera, are the last allegorical interpretations of the Circe myth as well as last important literary works on Ulysses for the next two-hundred years. ${ }^{10}$ Similarities or parallels between these plays are significant. Both authors went quite far away from classical sources and tradition, resolving moral problems in quite a pessimistic manner. Despite textual declarations of Amalteo it is not possible to defeat sexual desire and love by reason and virtues of constancy and temperance. ${ }^{11}$ Even Giove is not able to resolve the question posed by Mercurio

\footnotetext{
${ }^{9}$ Calderón served as a playwright at the court of Philip IV who also gave him some honours and position as a chaplain in Capilla de los Reyes Nuevos in Toledo's cathedral. Many of Calderón's plays were set to music, including El mayor encanto, amor (for the first time in Amsterdam 1670, composer unknown; Sullivan 1985: 79).

${ }^{10}$ The revival of interest in Ulysses' theme started with Goethe's planned tragedy Ulysses auf Phäa (1786; Stanford 1963: 190-193; Witte 1999: 33-34).

${ }^{11}$ Temperantia was connected to Ulysses in some Renaissance works of art, e.g. the famous picture by Giovanni Stradano Ulisse, Circe e i compagni (1561-1563), Palazzo Vecchio, Florence. The source here is Homeric Allegories (70) by Heraclitus (see the interpretation: Conticelli 2011: 249-251).
} 
and Venere and their quest. He must switch from moral into political terms and problems, and to employ the goddess of love in the final chorus (Choro di Tutti). Unfortunately, the reader does not know why he excludes from this final eulogy Mercurio (who is for Homer also a symbol of male sexuality). The god - probably - stays alone in the corner of the stage, away from the common joy of gods and spectators:

Così saggia e così forte,

Così amante e così chiara.

Si prepara,

De la terra à far un Cielo, la gran coppia; e in bassa parte, Fra Citera, e'1 Dio di Delo, Far regnar Pallade, e Marte.

\author{
So wise and so strong, \\ So loving and so pure \\ The high couple \\ Prepare to transform \\ Earth into a heaven; here below, \\ Between Venus and Apollo \\ They crown Pallas and Mars.
}

The very peculiar theology of Calderón in Los encantos de la culpa did not allow El Hombre-Ulysses to escape from his desire; it is rather the cause of love, not sin. Circe shows to his lover new, sensual mode to experience and explore the world. It was fate that decided that he had to fall in love and now, after a time of pleasure and freedom, he had to return to the order, reason, and authority. Even his reason had to be changed by overcoming his own hubris (see Stanford 1963: 187-190; Yarnall 1994: 159-162; Biały 1997: XCV-C). He managed to fight of the temptation but he is not happy and is taken by La Penitencia-Iris not fully voluntarily (“jay de mí!” - 'alas!'), still yearning for Circe:

Circe, poco tus encantos

han podido, pues me saca,

(¡ay de mí!) la Iris divina

coronado de esperanzas.

(Calderón 2004: 241)
Circe, now thy sorceries vile

Harm me not, since from thy meshes

Faith, the heavenly Iris, leads me

With Hope's glory round my temples.

(Calderón 1861: 203-204)

Only Circe must stay on her island unmoved, untransformed, turned toward her own past, without any hope and - paradoxically - any message for Ulysses concerning his further voyage and adventures. The last words of La Culpa-Circe are:

Confúndanse los palacios

y volviéndose montañas

oscuras no viva en ellas

sino yo, pues que me saca

a quien encantando tuve

la Penitencia sagrada
Palaces sink down in ruin,

And the dark hills that upheld them,

Reappear in all their wildness -

I sole dweller in the desert:

For from me hath holy Penance

Him released, whom charm'd I held here, 
en virtud de aquel divino manjar que da por vïanda. (Calderón 2004: 242)
By the virtue this divinest

Bread, this heavenly food, possesses.

(Calderón 1861: 204)

\section{Ulisse all'Isola di Circe - Neo-Stoic admonishment?}

What is the message of Amalteo's retold story of Ulysses and Circe? Is it a kind of Neo-Stoic admonishment on the fifth of the Stoic paradoxes discussed in detail by using classical quotations in the most famous manual by Justus Lipsius: "Sapientem Apathem \& Imperturbabilem esse. Pluscula hic de Affectibus" ["The sage should be free from all passions and undisturbable. Here also some more on emotions."] (Lipsius 1604: 151). "In sapientem nulla cadit perturbatio: sive: Sapiens caret affectibus" ["The sage does not yield to commotion, i.e., he is free of emotions."] - we read in another manual (Schoppe 1606: 67v). The answer is not simple. The intervention or even violence and vengeance of Venere mean that Circe without the goddess' help is unable to conquer Ulisse despite his passiveness and effeminacy. She is only an allegory of sensuality, sensual but also sentimental, in opposition to Homeric heroine (see Segal 1968: 424-425). Amalteo follows Vergil stressing Circe's sexuality and eliminating her human and positive dimension, as well as Ovid using examples of Picus and Glaucus as an evidence of the danger of Circe's passions and desire, witchcraft and enchantment (see Segal 1968: 430, 438, 440). The very clear sign of it is transformation into marble statues. Ulisse is extremely passive in opposition to his Homeric model. His virtue is only a declaration and he needs additional inspiration and admonitions of Mercurio to change his position and move on. His yearning for home and family is frozen, as it was explained in the argument of the opera (see Louden 2007: 171). There is no trace of the original search for knowledge and wisdom (see Montiglio 2011: 150). Amalteo's Circe is not any more a voluntary helper for Ulysses, the most important female character who by giving twice advices and detailed instruction makes his journey safer and announces his ability to choose ways wisely after passing by the Sirens' island (see Louden 2007: 64-65, 178-180). Finally, all gods are employed in a political eulogy. Both Ulisse and Circe are forgotten by them. They only fulfilled the scenario prepared by Mercurio, and - obviously - Amalteo. This way the stoic problem is dissolved. 


\section{Bibliography}

Amalteo, Ascanio. 1650. Ulisse all'Isola di Circe. Dramma musicale. Brusselles: Apresso d'Huberto Antonio Velpio.

Badoaro, Giacomo. 1644a. Scenario Dell' "Ulisse errante. Opera musicale." [...]. Venetia: Pietro Pinelli. . 1644b. Ulisse errante. Opera musicale. Venetia: Pietro Pinelli.

Biały, Leszek. 1997. “Wstęp." Calderon de la Barca, Pedro. Autos sacramentales: Wielki teatr świata, Magia grzechu, Życie jest snem. Ed. and trans. Leszek Biały. Wrocław: Ossolineum.

Boccaccio, Giovanni. 1511. Genealogiae Joannis Boccatii cum demonstrationibus in formis arborum designata. [Genealogia deorum gentilium.]. Venetiis: Augustinus de Zannis. . 1963. Concerning Famous Women. Ed. and trans. Guido A. Guarino. New Brunswick New Jersey: Rutgers University Press.

. 2013. O stynnych kobietach [bilingual edition]. Eds and trans. Piotr Bańkowski, Inga Grześczak, and Agnieszka Szopińska. Warszawa: Wydawnictwa Uniwersytetu Warszawskiego.

Brumble, H. David. 1998. Classical Myths and Legends in the Middle Ages and Renaissance: A Dictionary of Allegorical Meanings. Westport, Connecticut: Greenwood Press.

Calderón de la Barca, Pedro. 1861. Love the Greatest Enchantment: The Sorceries of Sin: The Devotion of the Cross. Trans. Denis Florence MacCarthy. London: Longman, Green, Longman and Roberts.

. 2004. Los encantos de la culpa. Estudio de Aurora Egido. Edición de Juan Manuel Escudero. Kassel: Edition Reichenberger - Pamplona: Universidad de Navarra.

Capodieci, Luisa, and Ford, Philip, eds. 2011. Homère à Renaissance: Mythe et transfiguration. Rome: Académie de France à Rome.

Comes, Natalis. 1612. Natalis Commitis Mythologiae, sive explicationis fabularum libri decem [...]. Genevae: Samuel Crispinus.

Conticelli, Valentina. 2011. “Omero (e Porfirio) a Palazzo Vecchio: le virtù di Ulisse nella Sala di Penelope." Eds Capodieci, Luisa, and Philip Ford. 241-265.

Haas, Robert. 1920-1921. “Gioseppe Zamponis Ulisse nell' Isola di Circe." Zeitschrift für Musikwissenschaft 3: 385-405.

Jong, Irene J. F. de. 2001. A Narratological Commentary on the "Odyssey." Cambridge: Cambridge Univ. Press.

Kuhn, Barbara. 2003. Mythos und Metapher: Metamorphosen des Kirke-Mythos in der Literatur der italienischen Renaissance. München: Wilhelm Fink Verlag.

Lipsius, Justus. 1604. Ivsti Lipsi Manvdvctionis Ad Stoicam Philosophiam Litri Tres [...]. Antverpiae: Ex Officina Plantiniana.

Louden, Bruce. 2007 [1999]. "Kalypso and the Function of Book Vive." Homer's "The Odyssey." . Ed. Harold Bloom. New York: Bloom's Literary Criticism. 169-196.

Montiglio, Silvia. 2011. From Villain to Hero: Odysseus in Ancient Thought. Ann Arbor: The Univ. of Michigan Press.

Ovid. 1916. Metamorphoses. With an English translation by Frank Justus Miller. I-II. London and Cambridge, Mass.: Harvard Univ. Press.

Rahner, Hugo. 1971. Greek Myths and Christian Mystery. Trans. Brian Battershaw. New York: Harper \& Row. 
Rasch, Rudolf. 1999. “Opera in Netherlands." Spectaculum Europæum: Theater and Spectacle in Europe (1580-1750). Eds Pierre Béhar, and Helen Watanabe-O'Kelly. Wiesbaden: Harrassowitz. 429-435.

Schoppe, Caspar. 1606. Casp. Scioppii Elementa Philosophiae Stoicae Moralis [...]. Moguntiae: Ex Calcographeo Ioannis Albini.

Segal, Charles. 1968. "Circean Temptations: Homer, Vergil, Ovid." Transactions and Proceedings of the American Philological Association 99: 419-442.

Solomon, Jon. 2014. "The Influence of Ovid in Opera." A Handbook to the Reception of Ovid. Eds John F. Miller, and Carole E. Newlands. Oxford: John Willey \& Sons. 371-385.

Stanford, W. B. 1963 [1954]. The Ulysses Theme: A Study in the Adaptability of a Traditional Hero. 2 revised ed. Oxford: Basil Blackwell.

Sullivan, Henry W. 1985. "Calderon and Semi-Operatic Stage in Spain after 1651." Calderon and the Baroque Tradition. Eds Kurt Levy, Jesus Ara, and Gethin Hughes. Waterloo, Ontario: Wilfrid Laurier Univ. Press. 69-80.

T'Hooft, Sigrid. 2008. "Italianità in Brussels around 1650: The Opera Ulisse nell'isola di Circe by Giuseppe Zamponi." Italian Opera in Central Europe 1614-1780. II: Italianità: Image and Practice. Eds Corinna Herr, Herbert Seifert, Andrea Sommer-Mathis, and Reinhard Strohm. Berlin: BWV Berliner Wissenschafts-Verlag. 87-102.

Tochtermann, Sibylle. 1992. Die allegorische gedeutete Kirke Mythos: Studien zur Entwicklungs- und Rezeptionsgeschichte. Frankfurt am Main: Peter Lang.

Witte, Bernd. 1999. "Goethe und Homer: Ein Paradigmenwechsel." Goethes Rückblick auf Antike: Beiträge des deutsch-italienischen Kolloquiums Rom. Eds Bernd Witte, and Mauro Ponzi. Berlin: Erich Schmidt. 21-37.

Yarnall, Judith. 1994. Transformations of Circe: The History of Enchantress. Urbana and Chicago: Univ. of Illinois Press. 